Shakespeare's Schoolroom 



\title{
Shakespeare’s Schoolroom
}

Rhetoric, Discipline, Emotion

\author{
Lynn Enterline
}

\section{PENN}

UNIVERSITY OF PENNSYLVANIA PRESS

PHILADELPHIA 
Copyright (C) 2012 University of Pennsylvania Press

All rights reserved. Except for brief quotations used for purposes of review or scholarly citation, none of this book may be reproduced in any form by any means without written permission from the publisher.

Published by

University of Pennsylvania Press

Philadelphia, Pennsylvania I9IO4-4II2

www.upenn.edu/pennpress

Printed in the United States of America on acid-free paper

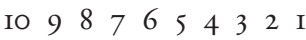

Library of Congress Cataloging-in-Publication Data Enterline, Lynn, I956-

Shakespeare's schoolroom : rhetoric, discipline, emotion / Lynn Enterline. — Ist ed.

p. $\mathrm{cm}$.

Includes bibliographical references and index. ISBN 978-0-8I22-4378-9 (hardcover : alk. paper)

I. Shakespeare, William, 1564-1616-Knowledge and learning. 2. English drama-I6th century-Classical influences. 3. Education, Secondary-EnglandCurricula-History-I6th century. I. Title.

PR2903.E58 2012

$822.3^{\prime} 3-\mathrm{dc} 23$ 